\title{
HUBUNGAN ANTARA KARAKTERISTIK IBU DENGAN KELENGKAPAN IMUNISASI DASAR DI PUSKESMAS WONOKUSUMO KOTA SURABAYA
}

\section{THE CORRELATION BETWEEN MOTHER CHARACTERISTICS AND COMPLETE BASIC IMMUNIZATION IN WONOKUSUMO COMMUNITY HEALTH SERVICE, SURABAYA}

\author{
Larassita Rakhmanindra $^{1}$, Nunik Puspitasari ${ }^{1}$ \\ ${ }^{1}$ Departemen Biostatistika dan Kependudukan, \\ Fakultas Kesehatan Masyarakat, Universitas Airlangga, Surabaya, Indoneisa \\ Alamat Korespondensi: Larassita Rakhmanindra \\ Email: larassitar@yahoo.com
}

\begin{abstract}
:
Immunization is one of the main activities implemented by the Ministry of Health in order to decrease the number of child pain and mortality caused by diseases that can be prevented by immunization (PD3I). This research aims to analyze the correlation between the mother characteristics and complete basic immunization on infants at Wonokusumo Community Health Service, Semampir District, Surabaya. The research is analytical study by employing cross-sectional design. The research samples were 86 mothers taken by using simple random sampling techniques. The data collection was carried out by conducting interview based on the existing questionnaire to mothers with 1-2 years children in Wonokusumo area. The analyzed variables were mother's age, knowledge, employment status, income level, antinatal maternal status, and motivation. The data analysis was carried out by Chi-Square.The results show that there is a correlation of the mothers' formal education ( $p=0.005)$, mothers' knowledge about immunization $(p=0.000)$, income level $(p=0.018)$, antenatal maternal status $(p=0.000)$, and the mother's motivation $(p=0.000)$ and complete basic immunization. Meanwhile, the mothers' age $(p=0.849)$ and mothers' employment status $(p=0.059)$ have no correlation with the complete basic immunization. In conclusion, the mother's formal education, knowledge about immunization, income level, antenatal maternal status, and motivation are crucial matters in conducting complete basic immunization.
\end{abstract}

Keywords: complete basic immunization, education, income level, mothers' motivation.

\begin{abstract}
ABSTRAK:
Imunisasi merupakan salah satu kegiatan prioritas yang dilakukan oleh Kementerian Kesehatan guna dalam menurunkan angka kesakitan dan kematian anak yang disebabkan oleh penyakit yang dapat dicegah dengan imunisasi (PD3I). Tujuan penelitian ini adalah menganalisis hubungan karakteristik ibu dengan kelengkapan imunisasi dasar pada bayi di Puskesmas Wonokusumo Kecamatan Semampir Kota Surabaya. Jenis penelitian yang digunakan ialah studi analitik, dengan desain penelitian cross sectional. Sampel penelitian sebesar 86 ibu, diambil secara simple random sampling. Pengumpulan data dilakukan dengan wawancara berdasarkan kuesioner yang telah disiapkan sebelumnya kepada ibu yang memiliki anak berusia 1-2 tahun di wilayah Wonokusumo. Variabel yang diteliti ialah umur ibu, pendidikan formal ibu, pengetahuan ibu, status bekerja ibu, tingkat pendapatan, status antenatal ibu, dan motivasi ibu. Analisis data yang digunakan dalam penelitian ini adalah Chi Square.Hasil penelitian menunjukkan terdapat hubungan antara pendidikan formal ibu $(p=0,005)$, pengetahuan ibu tentang imunisasi $(p=0,000)$, tingkat pendapatan $(p=0,018)$, status antenatal ibu $(p=0,000)$ dan motivasi ibu $(p=0,000)$ dengan kelengkapan imunisasi dasar, sedangkan umur ibu $(p=0,849)$ dan status bekerja ibu $(p=0,059)$ tidak terdapat hubungan dengan kelengkapan imunisasi dasar. Kesimpulan dari penelitian ini adalah pendidikan formal, pengetahuan tentang imunisasi, tingkat pendapatan, status antenatal dan motivasi ibu merupakan hal yang sangat penting dalam melakukan imunisasi dasar secara lengkap.
\end{abstract}

Kata kunci: imunisasi dasar lengkap, pendidikan, pendapatan, motivasi ibu

\section{PENDAHULUAN}

Penyakit yang disebabkan oleh infeksi masih banyak terjadi di negara berkembang, termasuk Indonesia. Penyakit infeksi merupakan salah satu sebab terbesar dari terjadinya kematian anak. Upaya preventif merupakan bidang prioritas yang efektif dalam mewujudkan tujuan pembangunan kesehatan. Pada sistem kesehatan nasional, imunisasi merupakan salah satu cara preventif dalam mencegah 
terjadinya penyakit infeksi menular terutama pada bayi dan balita. Adanya upaya preventif dalam mencegah penularan penyakit menular pada bayi dan balita, diharapkan akan menurunkan pula angka kematian bayi dan balita (Achmadi, 2006).

Imunisasi merupakan suatu program yang dengan sengaja memasukan antigen lemah agar merangsang antibody keluar sehingga tubuh akan resisten terhadap penyakit tertentu (Proverawati, 2010). Imunisasi dapat mencegah 2-3 juta kematian anak. Imunisasi dasar lengkap dilakukan sebagai upaya preventif dalam mencegah penyakit menular seperti campak, hepatitis b, polio, difteri, tetanus dan pertusis. Selain itu imunisasi merupakan upaya intervensi kesehatan manusia yang paling berhasil dan cost-effective, terutama bagi negara berkembang (WHO, 2012).

Pada hakekatnya masalah imunisasi tidak luput dari perhitungan untung dan rugi. Keuntungan dari imunisasi tidak terlihat secara materi mungkin tidak pula langsung dirasakan. Anak yang mendapat imunisasi jarang menderitas sakit parah dan pertumbuhannya berjalan normal. Sebaliknya pada anak yang tidak mendapat imunisasi akan lebih besar risikonya untuk mengalami sakit parah dan pertumbuhannya terhambat, bahkan berisiko dapat terjadi kematian. Masalah manfaat dan keuntungan yang tidak langsung dapat dirasakan ini merupakan salah satu hambatan terlaksananya imunisasi (Achmadi, 2006).

Berdasarkan laporan info Pusat Data dan Informasi Kementerian Kesehatan RI, pada tahun 2015 sebanyak 3 provinsi yang melaporkan bahwa cakupan desa/kelurahan UCI sebesar $100 \%$, yaitu DKI Jakarta, D.I Yogyakarta, dan Jawa Tengah. Pada realitanya cakupan UCI Jawa Timur berada di bawah rata-rata cakupan UCI Indonesia.

Pada tahun 2015 dilaporkan bahwa UCI di Surabaya mencapai 85,71\% dari 154 Kelurahan yang terdapat di Kota Surabaya. Cakupan imunisasi dasar di Kota Surabaya pada tahun 2015 yaitu: Imunisasi Hepatitis B kurang dari 7 hari $(84,95 \%)$, BCG (92,15\%), Imunisasi DPT3+HB3 $(92,18 \%)$, Imunisasi Polio 4 (91,71\%), Imunisasi
Campak (93,75\%). Cakupan imunisasi dasar lengkap di Kota Surabaya tahun 2015 sebesar 93,77 \% (Profil Kesehatan Kota Surabaya, 2015).

Target imunisasi dasar Kota Surabaya pada tahun 2016 adalah 91,5\%. Pada beberapa puskesmas di Kota Surabaya masih terdapat yang masih belum mencapai target UCI. Puskesmas Wonokusumo merupakan daerah terendah cakupan imunisasi dasar lengkapnya yaitu 58,9\% dengan rincian sebagai berikut: HB kurang dari 7 hari 34,0\%, BCG 53,5\%, DPT3+HB3 $57,8 \%$, Polio 59,8\%, dan Campak 58,9\%. Tahun 2014-2017 cakupan imunisasi Puskesmas Wonokusumo mengalami penurunan.

Terdapat beberapa alasan mengapa ibu tidak mengimunisasi anaknya, yaitu ibu takut akan efek samping dari imunisasi, saat jadwal imunisasi anak sedang sakit, dan tidak percaya akan manfaat dari imunisasi. Menurut Riskesdas tahun 2013 alasan anak tidak dimunisasi antara lain karena takut anaknya panas akibat imunisasi yang diberikan, keluarga tidak mengizinkan anak untuk di imunisasi, tempat imunisasi jauh, kesibukan orang tua, seringnya anak sakit, dan tidak tahu tempat imunisasi. Berdasarkan karakteristik ibu didapatkan cakupan imunisasi dasar lengkap anak tertinggi adalah pada ibu dengan pendidikan lulus perguruan tinggi, dan semakin tinggi sosial ekonomi keluarga maka semakin tinggi persentase imunisasi dasar lengkap pada anak (Kemenkes RI, 2013).

Terdapat beberapa faktor yang dapat mempengaruhi keputusan ibu utuk mengimunisasi anaknya, yaitu umur, tingkat pendidikan, tingkat pendapatan, status bekerja, tingkat pengetahuan, fasilitas kesehatan, dukungan orang sekitar dan lainnya. Faktor predisposisi (predisposing factor) yang terdiri atas umur ibu, tingkat pendidikan formal ibu, pengetahuan tentang imunisasi ibu, status bekerja ibu, tingkat pendapatan, status antenatal ibu, dan motivasi ibu. Pada faktor predisposisi (predisposing factor) ini terdapat batasan variabel independen penelitian yang tidak diteliti karena keterbatasan peneliti. 
Tujuan dari penelitian ini adalah Menganalisis hubungan karakteristik ibu yang terdiri dari dengan kelengkapan imunisasi dasar pada bayi di Puskesmas Wonokusumo Kota Surabaya.

\section{METODE PENELITIAN}

Jenis penelitian yang digunakan ialah studi analitik karena untuk melakukan analisis hubungan antara karakteristitik ibu dangan kelengkapan imunisasi dasar lengkpa. Rancang bangun penelitian yang digunakan adalah dengan cross sectional.

Populasi pada penelitian ini adalah ibu yang memiliki anak yang telah melewati masa imunisasi dasar pada tahun 2016 berdasarkan data cakupan imunisasi di wilayah kerja Puskesmas Wonokusumo Kecamatan Semampir Kota Surabaya. Jumlah populasi tersebut adalah 1094 ibu bayi.

Sampel di dalam penelitian ini adalah sebagian ibu yang memiliki anak usia 1-2 tahun dari keseluruhan di Puskesmas Wonokusumo dengan jumlah sampel sebesar 86 ibu. Hasil besar sampel didapatkan dari rumus Lemeshow (1997):

$$
\mathrm{n}=\frac{N \cdot Z_{1-\frac{\alpha}{2}}^{2} \cdot P(1-P)}{(N-1) d^{2}+Z_{1-\frac{\alpha}{2}}^{2} \cdot P(1-P)}
$$

maka didapat sampel minimal dalam penelitan ini:

$$
\begin{aligned}
\mathrm{n} & =\frac{1094(1,96)^{2} \cdot 0,59(1-0,59)}{(1094-1)(0,1)^{2}+(1,96)^{2} .0,59(1-0,59)} \\
& =\frac{1008,65}{11,85} \\
& =85,12
\end{aligned}
$$

Teknik pengambilan sampel yang digunakan di penelitian ini adalah menggunakan Simple Random Sampling yaitu metode pengambilan secara acak dimana masing-masing mempunyai peluang yang sama besar untuk terpilih sebagai sampel.
Penelitian dilakukan di wilayah kerja Puskesmas Wonokusumo Kecamatan Semampir Kota Surabaya. Lokasi ini dipilih sebagai lokasi penelitian karena memiliki cakupan imunisasi dasar yang terendah dari seluruh wiliyah kerja Puskesmas di Surabaya. Waktu penelitian ini dilaksanakan pada bulan April 2017 sampai Juli 2017.

Instrumen penelitian menggunakan kuesioner yang telah disiapkan sebelumnya. Variabel independen terdiri dari umur ibu, pendidikan formal ibu, pengetahuan ibu tentang imunisasi, status bekerja ibu, tingkat pendapatan, status antenatal ibu, dan motivasi ibu, sedangkan variabel dependennya ialah kelengkapan imunisasi dasar. Analisis data dalam penelitian ini menggunakan uji Chi squre. Penelitian ini telah memperoleh keterangan lolos kaji etik dari Komisi Etik FKM No : 342-KEPK.

\section{HASIL}

Puskesmas Wonokusumo merupakan salah satu puskesmas yang berada di wilayah Kecamatan Semampir Kota Surabaya. Puskesmas Wonokusumo terdiri dari puskesmas induk dan pembantu. Wilayah kerja Puskesmas Wonokusumo adalah Kelurahan Wonokusumo yang terbagi atas $16 \mathrm{RW}$ dan $166 \mathrm{RT}$. Status kelengkapan imunisasi dasar adalah lengkap atau tidaknya imunisasi yang diperoleh balita tersebut mulai dari Hepatitis B, BCG, DPT, Polio dan Campak. Hasil penelitian kelengkapan imunisasi sebagai berikut:

Tabel 1. Distribusi Responden Menurut Status Kelengkapan Imunisasi di Puskesmas Wonokusumo

\begin{tabular}{lcc}
\hline $\begin{array}{c}\text { Status Kelengkapan } \\
\text { Imunisasi Dasar }\end{array}$ & Jumlah & \% \\
\hline Tidak Lengkap & 32 & 37,21 \\
Lengkap & 54 & 62,79 \\
\hline Jumlah & 86 & 100,00 \\
\hline
\end{tabular}

Berdasarkan Tabel 1. diketahui bahwa $37,21 \%$ ibu yang memiliki balita dengan status kelengkapan imunisasi dasar yang tidak lengkap dan sisanya 62,79\% berstatus lengkap. Terdapat beberapa alasan 
mengapa ibu tidak mengimunisasi balitanya, yaitu: Sakit saat jadwal imunisasi $(59,38 \%)$, takut akan efek samping imunisasi $(34,38 \%)$, dan tidak percaya akan imunisasi $(6,25 \%)$.

\section{Umur Ibu}

Kategori umur ibu berdasarkan dari umur ideal seorang wanita menikah dan siap memiliki anak menurut BKKBN. Perbedaan umur ibu berhubungan dengan tingkat paparan dan tingkat pengalaman yang dimiliki. Perbedaan keterpaparan dan tingkat pengalaman akan berpengaruh pada pengambilan keputusan kesehatan.
Berdasarkan usia ibu, terdapat $40 \%$ ibu yang berusia kurang dari 20 tahun memiliki anak dengan imunisasi tidak lengkap. Ibu yang berumur 20 tahun atau lebih, sebanyak $37,04 \%$ diantaranya memiliki anak dengan imunisasi dasar tidak lengkap. Terdapat $60 \%$ ibu yang berusia kurang dari 20 tahun memiliki anak dengan imunisasi dasar lengkap. Sementara pada ibu berumur 20 tahun atau lebih terdapat $62,96 \%$ diantaranya memiliki anak dengan imunisasi dasar lengkap. Tidak ada perbedaan yang signifikan antara proporsi imunisasi dasar lengkap dan tidak lengkap menurut usia ibu (nilai $p=0,849$ ).

Tabel 2.Analisis Bivariate antara Umur Ibu dan Kelengkapan Imunisasi Dasar di Puskesmas Wonokusumo Tahun 2017

\begin{tabular}{|c|c|c|c|c|c|c|c|c|}
\hline & \multirow{2}{*}{ Variabel } & \multicolumn{2}{|c|}{$\begin{array}{c}\text { Imunisasi Tidak } \\
\text { Lengkap }\end{array}$} & \multicolumn{2}{|c|}{$\begin{array}{l}\text { Imunisasi } \\
\text { Lengkap }\end{array}$} & \multicolumn{2}{|c|}{ Jumlah } & \multirow{2}{*}{$p-$ value } \\
\hline & & $\mathbf{n}$ & $\%$ & $\mathbf{n}$ & $\%$ & $\mathbf{n}$ & $\%$ & \\
\hline \multirow{2}{*}{ Usia } & $<20$ tahun & 2 & 40,0 & 3 & 60,00 & 5 & 100,0 & \multirow{3}{*}{$0,849 *$} \\
\hline & $\geq 20$ tahun & 30 & 37,04 & 51 & 62,96 & 81 & 100,0 & \\
\hline & Jumlah & 32 & 37,21 & 54 & 62,79 & 86 & 100,0 & \\
\hline
\end{tabular}

*signifikansi pada $\alpha=0,05$

\section{Pendidikan Fomal Ibu}

Pendidikan formal ibu di kategorikan menjadi pendidikan ibu kurang dari sama dengan 9 tahun dan pendidikan ibu lebih dari 9 tahun. Pendidikan ibu kurang dari sama dengan 9 tahun adalah dimana pendidikan yang telah di selesaikan ibu paling tinggi sampai sekolah menengah pertama (SMP/sederajat) sedangkan, pendidikan lebih dari 9 tahun adalah dimana ibu paling tidak telah pernah memasuki ranah sekolah menengah atas (SMA/sederajat). Ibu yang telah melewati masa pendidikan formal lebih dari 9 tahun akan cenderung mengimunisasi anaknya daripada ibu yang melewati pendidikan formal tidak lebih dari 9 tahun. Berdasarkan pendidikan ibu terdapat $53,66 \%$ ibu yang telah menjalani pendidikan formal selama 9 tahun atau kurang memiliki anak dengan imunisasi dasar tidak lengkap. Ibu yang telah menjalani pendidikan formal lebih dari 9 tahun, sebanyak $77,78 \%$ diantaranya memiliki anak dengan imunisasi dasar lengkap.

Terdapat perbedaan yang signifikan antara proporsi imunisasi dasar lengkap dan tidak lengkap menurut pendidikan formal ibu (nilai $p=0,005$ ). Nilai koefisien kontingensi 0,325 yang berartikan hubungan yang dimiliki tidak begitu kuat karena nilai tersebut mendekati nilai 0 .

\section{Pengetahuan Ibu}

Pada variabel pengetahuan ibu dikategorikan menjadi 3 kategori yaitu, pengetahuan rendah, pengetahuan sedang dan pengetahuan tinggi. Berdasarkan pengetahuan ibu, terdapat $90,90 \%$ ibu yang memiliki pengetahuan tentang imunisasi rendah memiliki anak dengan imunisasi 
yang tidak lengkap. Terdapat $96 \%$ ibu yang memiliki pengetahuan tentang imunisasi tinggi memiliki anak dengan imunisasi dasar lengkap. Terdapat perbedaan yang signifikan antara proporsi imunisasi dasar lengkap dan tidak lengkap menurut pengetahuan ibu tentang imunisasi dasar lengkap (nilai $p=0,000$ ). Nilai koefisien kontingensi menunjukan 0,812 yang berartikan hubungan yang dimiliki cukup kuat karena nilai tersebut mendekati nilai 1.

Tabel 3. Analisis Bivariate antara Pendidikan Formal Ibu dan Kelengkapan Imunisasi Dasar di Puskesmas Wonokusumo Tahun 2017

\begin{tabular}{|c|c|c|c|c|c|c|c|c|}
\hline \multirow{2}{*}{\multicolumn{2}{|c|}{ Variabel }} & \multicolumn{2}{|c|}{$\begin{array}{c}\text { Imunisasi Tidak } \\
\text { Lengkap }\end{array}$} & \multicolumn{2}{|c|}{$\begin{array}{l}\text { Imunisasi } \\
\text { Lengkap }\end{array}$} & \multicolumn{2}{|c|}{ Jumlah } & \multirow{2}{*}{$p$-value } \\
\hline & & $\mathbf{n}$ & $\%$ & $\mathbf{N}$ & $\%$ & $\mathbf{n}$ & $\%$ & \\
\hline Pendidikan & $\leq 9$ tahun & 22 & 53,66 & 19 & 46,34 & 41 & 100,0 & \multirow{3}{*}{$0,005^{*}$} \\
\hline Formal Ibu & $>9$ tahun & 10 & 22,22 & 35 & 77,78 & 45 & 100,0 & \\
\hline \multicolumn{2}{|c|}{ Jumlah } & 32 & 37,21 & 54 & 62,79 & 86 & 100,0 & \\
\hline
\end{tabular}

*signifikansi pada $\alpha=0,05$

Tabel 4.Analisis Bivariate antara Pengetahuan Ibu dan Kelengkapan Imunisasi Dasar di Puskesmas Wonokusumo Tahun 2017

\begin{tabular}{|c|c|c|c|c|c|c|c|c|}
\hline \multirow{2}{*}{\multicolumn{2}{|c|}{ Variabel }} & \multicolumn{2}{|c|}{$\begin{array}{c}\text { Imunisasi Tidak } \\
\text { Lengkap }\end{array}$} & \multicolumn{2}{|c|}{$\begin{array}{l}\text { Imunisasi } \\
\text { Lengkap }\end{array}$} & \multicolumn{2}{|c|}{ Jumlah } & \multirow{2}{*}{$p$-value } \\
\hline & & $\mathbf{n}$ & $\%$ & $\mathbf{n}$ & $\%$ & $\mathbf{n}$ & $\%$ & \\
\hline Pengetahuan & Rendah & 10 & 90,90 & 1 & 9,10 & 11 & 100,0 & \multirow{4}{*}{$0,000^{*}$} \\
\hline Ibu & Sedang & 20 & 80,00 & 5 & 20,00 & 25 & 100,0 & \\
\hline & Tinggi & 2 & 4,00 & 48 & 96,00 & 50 & 100,0 & \\
\hline \multicolumn{2}{|c|}{ Jumlah } & 32 & 37,21 & 54 & 62,79 & 86 & 100,0 & \\
\hline
\end{tabular}

*signifikansi pada $\alpha=0,05$

\section{Status Bekerja Ibu}

Status bekerja ibu ditunjukkan untuk melihat apakah ibu memiliki penghasilan atau tidak. Berdasarkan penghasilan tersebut maka akan didapatkan cara ibu dalam mendapat akses faslitas kesehatan. Selain itu pendapatan akan melihat waktu dan kegiatan ibu sehari-harinya, apakah ibu memiliki waktu luang yang cukup banyak atau tidak.

Berdasarkan status bekerja ibu, terdapat $43,75 \%$ ibu yang tidak bekerja memiliki anak dengan imunisasi dasar tidak lengkap. Sementara $81,82 \%$ ibu yang bekerja memiliki anak dengan imunisasi dasar lengkap. Tidak ada perbedan yang siginifikan antara proporsi imunisasi dasar lengkap dan tidak lengkap menurut status bekerja ibu (nilai $p=0,059$ ).

\section{Tingkat Pendapatan}

Tingkat pendapatan dikategorikan menjadi tingkat pendapat kurang dari $\mathrm{Rp}$.
3.296.212 dan lebih dari sama dengan Rp. 3.2296.212. Kategori ini dibedakan berdasarkan UMK Kota Surabaya. Pada hasil yang telah dilapangan diketahui bahwa masyarakat di wilayah wonokusumo merupakan masyarakat yang tegolong pada pendapatan menengah kebawah.

Berdasarkan tingkat pendapatan ibu, terdapat $45,90 \%$ ibu yang memiliki pendapatan kurang dari UMK memiliki anak dengan imunisasi dasar tidak lengkap. Ibu yang memiliki pendapatan sesuai UMK atau lebih, sebanyak $84 \%$ diantaranya memiliki anak dengan imunisasi dasar lengkap. Terdapat perbedaan yang signifikan antara proporsi imunisasi dasar lengkap dan tidak lengkap menurut tingkat pendapatan ibu (nilai $p=0,018$ ). Nilai koefisien kontingensi 0,281 yang berartikan hubungan yang dimiliki tidakbegitu kuat karena nilai tersebut mendekati nilai 0 . 


\section{Status Antenatal}

Status antenatal ibu dikategorikan menjadi kurang dari 4 kali dan lebih dari sama dengan 4 kali. Kategori ini berdasarkan dari jumlah minimal kunjungan antenatal yang dilakukan oleh ibu hamil.

Tabel 5.Analisis Bivariate antara Status Bekerja Ibu dan Kelengkapan Imunisasi Dasar di Puskesmas Wonokusumo Tahun 2017

\begin{tabular}{|c|c|c|c|c|c|c|c|c|}
\hline \multirow{2}{*}{\multicolumn{2}{|c|}{ Variabel }} & \multicolumn{2}{|c|}{$\begin{array}{c}\text { Imunisasi } \\
\text { Tidak Lengkap }\end{array}$} & \multicolumn{2}{|c|}{$\begin{array}{c}\text { Imunisasi } \\
\text { Lengkap }\end{array}$} & \multicolumn{2}{|c|}{ Jumlah } & \multirow[t]{2}{*}{$p$-value } \\
\hline & & $\mathbf{n}$ & $\%$ & $\mathbf{n}$ & $\%$ & $\mathbf{N}$ & $\%$ & \\
\hline Status & Tidak Bekerja & 28 & 43,75 & 36 & 56,25 & 64 & 100,0 & \multirow{3}{*}{$0,059^{*}$} \\
\hline Bekerja & Berkeja & 4 & 18,18 & 18 & 81,82 & 22 & 100,0 & \\
\hline \multicolumn{2}{|c|}{ Jumlah } & 32 & 37,21 & 54 & 62,79 & 86 & 100,0 & \\
\hline
\end{tabular}

*signifikansi pada $\alpha=0,05$

Tabel 6. Analisis Bivariate antara Tingkat Pendapatan dan Kelengkapan Imunisasi Dasar di Puskesmas Wonokusumo Tahun 2017

\begin{tabular}{|c|c|c|c|c|c|c|c|c|}
\hline \multirow{2}{*}{\multicolumn{2}{|c|}{ Variabel }} & \multicolumn{2}{|c|}{$\begin{array}{c}\text { Imunisasi } \\
\text { Tidak Lengkap }\end{array}$} & \multicolumn{2}{|c|}{$\begin{array}{l}\text { Imunisasi } \\
\text { Lengkap }\end{array}$} & \multicolumn{2}{|c|}{ Jumlah } & \multirow{2}{*}{$p$-value } \\
\hline & & $\mathbf{n}$ & $\%$ & $\mathbf{n}$ & $\%$ & $\mathrm{n}$ & $\%$ & \\
\hline Tingkat & $<\mathrm{UMK}$ & 28 & 45,90 & 33 & 54,10 & 61 & 100,0 & \multirow{3}{*}{$0,018^{*}$} \\
\hline Pendapatan & $\geq \mathrm{UMK}$ & 4 & 16,00 & 21 & 84,00 & 25 & 100,0 & \\
\hline \multicolumn{2}{|c|}{ Jumlah } & 32 & 37,21 & 54 & 62,79 & 86 & 100,0 & \\
\hline
\end{tabular}

*signifikansi pada $\alpha=0,05$

Berdasarkan status antenatal ibu, terdapat $85 \%$ ibu yang melakukan kunjungan antenatal kurang dari 4 kali memiliki anak dengan imunisasi dasar tidak lengkap. Ibu yang melakukan kunjungan antenatal sebanyak 4 kali atau lebih, sebanyak $77,27 \%$ diantaranya memiliki anak dengan imunisasi dasar lengkap.

Diketahui nilai $p$ adalah 0,000 . Nilai tesebut kurang dari 0,05 yang berartikan terdapat perbedaan yang signifikan antara proporsi imunisasi dasar lengkap dan tidak lengkap menurut status antenatal ibu. Nilai koefisien kontingensi diketahui sebesar 0,544 yang berartikan hubungan yang dimiliki tidak begitu kuat karena nilai tersebut mendekati nilai 0 .

\section{Motivasi Ibu}

Motivasi ibu dikategorikan menjadi motivasi rendah dan motivasi tinggi.
Motivasi ibu dikategorikan berdasarkan hasil wawancara sesuai kuesioner yang ada. Ibu yang memiliki motivasi yang tinggi diharapkan akan lebih melakukan imunisasi dasar lengkap daripada dengan ibu yang memiliki motivasi yang rendah.Berdasarkan motivasi ibu, terdapat $74,07 \%$ ibu yang memiliki motivasi akan imunisasi dasar rendah memilki anak dengan imunisasi dasar tidak lengkap. Ibu yang memiliki motivasi tinggi terdapat $79,66 \%$ yang memiliki anak dengan status imunisasi dasar lengkap.

Terdapat perbedaan signifikan antara proporsi imunisasi dasar lengkap dan tidak lengkap menurut motivasi ibu akan imunisasi dasar (nilai $p=0,000$ ). Nilai koefisien kontingensi 0,516 yang berartikan hubungan yang dimiliki tidak begitu kuat karena nilai tersebut mendekati nilai 0 . 
Tabel 7. Analisis Bivariate antara Status Antenatal Ibu dan Kelengkapan Imunisasi Dasar di Puskesmas Wonokusumo Tahun 2017

\begin{tabular}{|c|c|c|c|c|c|c|c|c|}
\hline \multicolumn{2}{|c|}{ Variabel } & \multicolumn{2}{|c|}{$\begin{array}{c}\text { Imunisasi } \\
\text { Tidak Lengkap }\end{array}$} & \multicolumn{2}{|c|}{$\begin{array}{l}\text { Imunisasi } \\
\text { Lengkap }\end{array}$} & \multicolumn{2}{|c|}{ Jumlah } & \multirow[t]{2}{*}{$p$-value } \\
\hline & & $\mathbf{n}$ & $\%$ & $\mathbf{N}$ & $\%$ & $\mathbf{n}$ & $\%$ & \\
\hline \multirow{2}{*}{$\begin{array}{l}\text { Status } \\
\text { Antenatal }\end{array}$} & $<4$ kali & 17 & 85,00 & 3 & 15,00 & 20 & 100,0 & \multirow{3}{*}{$0,000 *$} \\
\hline & $\geq 4$ kali & 15 & 22,73 & 51 & 77,27 & 66 & 100,0 & \\
\hline \multicolumn{2}{|c|}{ Jumlah } & 32 & 37,21 & 54 & 62,79 & 86 & 100,0 & \\
\hline
\end{tabular}

*signifikansi pada $\alpha=0,05$

Tabel 8. Analisis Bivariate antara Motivasi Ibu dan Kelengkapan Imunisasi Dasar di Puskesmas Wonokusumo Tahun 2017

\begin{tabular}{|c|c|c|c|c|c|c|c|c|}
\hline \multirow{2}{*}{\multicolumn{2}{|c|}{ Variabel }} & \multicolumn{2}{|c|}{$\begin{array}{c}\text { Imunisasi } \\
\text { Tidak Lengkap }\end{array}$} & \multicolumn{2}{|c|}{$\begin{array}{l}\text { Imunisasi } \\
\text { Lengkap }\end{array}$} & \multicolumn{2}{|c|}{ Jumlah } & \multirow[t]{2}{*}{$p$-value } \\
\hline & & $\mathbf{N}$ & $\%$ & $\mathbf{N}$ & $\%$ & $\mathbf{n}$ & $\%$ & \\
\hline \multirow{2}{*}{ Motivasi Ibu } & Rendah & 20 & 74,07 & 7 & 25,93 & 27 & 100,0 & \multirow{3}{*}{$0,000 *$} \\
\hline & Tinggi & 12 & 20,34 & 47 & 79,66 & 59 & 100,0 & \\
\hline \multicolumn{2}{|c|}{ Jumlah } & 32 & 37,21 & 54 & 62,79 & 86 & 100,0 & \\
\hline
\end{tabular}

*signifikansi pada $\alpha=0,05$

\section{PEMBAHASAN}

\section{Umur Ibu}

Umur merupakan salah satu karakteristik utama yang dimiliki oleh seseorang. Umur mempunyai hubungan dengan tingkat keterpaparan akan suatu pengalaman. Perbedaan pengalaman terhadap suatu kejadian masalah kesehatan dipengaruhi oleh umur seseorang. Hasil penelitian menunjukan nilai $p>\alpha$ yang berartikan bahwa tidak terdapat hubungan antara umur ibu dengan kelengkapan imunisasi dasar. Hasil ini sama dengan hasil dilakukan oleh Rini (2009), yang menunjukkan bahwa tidak terdapat hubungan antara umur ibu dengan kelengkapan imunisasi dasar. Penelitian ini menunjukkan bahwa perbedaan pengalaman dan pengambilan keputusan tidak dipengaruhi oleh umur. Hal ini menunjukkan bahwa umur tidak selalu dominan menunjang seseorang untuk berperilaku seperti halnya yang diungkapkan oleh Notoatmodjo (2003) bahwa seseorang berperilaku berdasarkan hasil bersama antara faktor internal maupun faktor eksternal.

Hasil penelitian ini sejalan dengan penelitian yang dilakukan oleh Rahmawati (2014) di Kota Surabaya, tepatnya di Kelurahan Krembangan Utara, bahwa tidak terdapat hubungan antara umur ibu dengan kelengkapan imunisasi. Penelitian yang sejalan lainnya adalah penelitian yang dilakukan oleh Sugiarti (2014) di Kabupaten Gresik dan penelitian yang dilakukan oleh Luke (2014) di West Kenya, dimana menunjukan bahwa tidak terdapat hubungan antara umur ibu dengan kelengkapan imunisasi dasar.

Terdapat penelitian lainnya yang tidak menunjukan hasil yang serupa, yaitu penelitian yang dilakukan oleh Rahmadhani (2013) di Kabupaten Magetan, dimana terdapat hubungan antara umur ibu dengan kelengkapan imunisasi. Usia ibu yang mengalami peningkatan dalam batas tertentu maka dapat meningkatkan pengalaman ibu dalam mengasuh anak, sehingga akan berpengaruh dalam upaya pencegahan dan penanggulangan timbulnya penyakit (Rizqiawan, 2008). 


\section{Pendidikan Formal Ibu}

Pendidikan formal yang telah dijalani ibu merupakan salah satu akses dalam mendapatkan pengetahuan. Selain itu, dengan pendidikan formal maka akses komunikasi dan pengalaman dengan institusi pendidikan lebih luas. Semakin tinggi pendidikan maka akses komunikasi dengan institusi pendidikan dan pengetahuan ibu akan semakin luas. Dengan hal tersebut diharapkan ibu akan memiliki pengetahuan yang luas tentang imunisasi dan cenderung melakukan imunisasi dasar lengkap pada bayinya.

Hasil penelitian menunjukan nilai $p$ $<\alpha$ yang berartikan bahwa terdapat hubungan antara pendidikan formal yang telah dijalani ibu dengan kelengkapan imunisasi dasar. Hasil ini sama dengan hasil penelitian yang dilakukan oleh Rini (2009) bahwa terdapat hubungan antara pendidikan ibu dengan kelengkapan imunisasi. Hal ini menunjukan bahwa kondisi pendidikan ibu di wilayah Wonokusumo masih sama sampai saat ini.

Hasil penelitian di Wonokusumo serupa dengan penelitian yang dilakukan oleh Rahmawati (2014) di Kota Surabaya tepatnya di Kelurahan Krembangan Utara, bahwa terdapat hubungan antara pendidikan formal ibu dengan kelengkapan imunisasi. Semakin tinggi pendidikan ibu akan berhubungan positif dengan kecenderungan untuk mengimunisasi bayinya. Penelitian serupa juga dilakukan oleh Sugiarti (2014) di Kabupaten Gresik, bahwa ibu yang memiliki pendidikan tinggi maka akan lebih mudah menerima dan mengerti tentang pesan-pesan imunisasi, sehingga diharapkan dapat menerapkan informasi yang diterimanya, yaitu memberikan imunisasi lengkap kepada anaknya.

Hasil penelitian lainnya yang menunjukan terdapat hubungan antara pendidikan formal ibu dengan kelengkapan imunisasi dasar adalah penelitian yang dilakukan oleh Nur (2010) di Yogyakarta. Selain itu terdapat hasil yang sama pada sesama negara berkembang yaitu penelitian yang dilakukan oleh Adebiyi (2013) di Nigeria dan Luke (2014) di Western Kenya.

\section{Pengetahuan Ibu}

Pengetahuan merupakan hal yang sangat penting dalam pembentukan perilaku seseorang (Notoatmodjo, 2003). Tingkat pengetahuan yang dimiliki ibu akan memberikan respon yang positif terhadap program kesehatan. Pengetahuan yang dimiliki ibu akan berpengaruh positif pada pengambilan keputusan dan perilaku ibu untuk mengimunisasi bayinya. Ibu yang memiliki pengetahuan yang tinggi dimungkikan akan memiliki peluang yang lebih besar untuk melakukan imunisasi pada bayinya.

Hasil penelitian menunjukan nilai $p$ $<\alpha$ yang berarti terdapat hubungan antara pengetahuan imunisasi yang dimiliki oleh ibu dengan kelengkapan imunisasi dasar. Hasil ini sama dengan hasil penelitian dilakukan oleh Rini (2009) bahwa terdapat hubungan antara pengetahuan imunisasi yang dimiliki oleh ibu dengan kelengkapan imunisasi. Hal ini menunjukkan bahwa pengetahuan yang dimiliki oleh para ibu di Wonokusumo masih menjadi variabel yang berhubungan dengan melakukan imunisasi pada bayinya.

Penelitian ini didukung pula dengan hasil penelitian yang dilakukan oleh Rahmawati (2014) di Kota Surabaya tepatnya di Kelurahan Krembangan Utara, bahwa terdapat hubungan antara pengetahuan imunisasi yang dimiliki ibu dengan kelengkapan imunisasi dasar. Tingkat pengetahuan ibu yang kurang berisiko untuk tidak melakukan imunisasi pada bayinya dan sebaliknya tingkat pengetahuan ibu yang tinggi akan cenderung untuk melakukan imunisasi dasar pada bayinya.

Penelitian ini didukung dengan penelitian yang dilakukan oleh Octaviani (2015) di Kabupaten Sampang, Isnayni (2016) di Kabupaten Lamongan, Nur (2010) di Yogyakarta, Triana (2015) di Padang, Indrawan (2014) di Kelurahan Airlangga dan Kelurahan Gubeng Kota Surabaya, dimana tedapat hubungan antara pengetahuan imunisasi yang dimiliki ibu dengan kelengkapan imunisasi dasar. Semakin baik tingkat pendidikan, maka 
semakin baik pula tingkat pengetahuan. Selain pendidikan, faktor-faktor yang mempengaruhi pada peningkatan pengetahuan seseorang adalah keikutsertaan dalam pelatihan atau penyuluhan. Pengetahuan seseorang dapat bertambah pula dengan cara memperkaya khasanah pengetahuan melalui membaca baik melalui media massa dan media elektrik (internet), walaupun tanpa melalui pendidikan formal (Senewe, 2017).

\section{Status Bekerja}

Kelompok ibu yang memberikan imunisasi dasar lengkap pada bayinya, terdapat kecenderungan lebih besar ibu yang bekerja daripada ibu yang tidak bekerja. Ibu yang bekerja memiliki risiko lebih besar untuk mengimunisasi bayinya dibandingkan degan ibu yang tidak bekeja. Hal tersebut dikarenakan ibu yang bekerja memiliki paparan informasi yang lebih banyak dibandingkan dengan ibu yang tidak bekerja atau sebagai ibu rumah tangga.

Hasil penelitian menunjukan nilai $p$ $>\alpha$ yang berartikan tidak terdapat hubungan antara status bekerja ibu dengan kelengkapan imunisasi dasar. Hasil ini sama dengan hasil penelitian yang dilakukan oleh Rini (2009) bahwa tidak terdapat hubungan antara status bekerja ibu dengan kelengkapan imunisasi. Hal ini menunjukkan bahwa status bekerja para ibu di Wonokusumo masih menjadi variabel yang tidak berhubungan dengan melakukan imunisasi pada bayinya.

Penelitian ini didukung pula dengan hasil penelitian yang dilakukan oleh Rahmawati (2014) di Kota Surabaya tepatnya di Kelurahan Krembangan Utara, bahwa tidak terdapat hubungan antara status bekerja ibu dengan kelengkapan imunisasi dasar. Kesamaan pada penelitian ini adalah rata-rata hasil jumlah ibu yang tidak bekerja atau sebagai ibu rumah tangga lebih besar daripada ibu yang bekerja. Keterkaitan kelengkapan imunisasi dapat dilihat dari berbagai faktor, salah satunya dengan tingkat pendidikan yang rendah dan dengan status bekerja. Kedua hal tersebut akan menyebabkan ibu tidak mendapatkan informasi mengenai pentingnya imunisasi dan dapat menyebabkan pengetahuan ibu menjadi kurang. Pendidikan yang rendah menyebabkan ibu tidak tahu manfaat yang terkandung dalam imunisasi bagi bayi atau balitanya.

Penelitian ini sejalan dengan penelitian Octaviani (2015) di Kabupaten Sampang, Isnayni (2016) di Kabupaten Lamongan, Nur (2010) di Yogyakarta, dan Triana (2015) di Padang, , dimana terdapat hubungan antara pengetahuan imunisasi yang dimiliki ibu dengan kelengkapan imunisasi dasar. Penelitian yang dilakukan oleh Adebiyi (2013) bertentangan dengan hasil penelitian ini, dimana terdapat hubungan antara status bekerja ibu dengan kelengkapan imunisasi.

\section{Tingkat Pendapatan}

Tingkat pendapatan merupakan komponen yang kuat dalam penentuan perilaku. Hal ini berhubungan dengan akses untuk mendapatkan fasilitas kesehatan. Tingkat pendapatan yang tinggi menandakan bahwa status ekonomi yang baik dan hal tersebut juga akan mempengaruhi dalam mendapatkan fasilitas kesehatan. Akses fasilitas kesehatan yang mudah didapat maka akan berpengaruh pada status kesehatan seseorang dalam arti ini ialah mendapatkan pelayanan imunisasi dasar.

Hasil penelitian menunjukan nilai $p$ $<\alpha$ yang berartikan terdapat hubungan antara tingkat pendapatan dengan kelengkapan imunisasi dasar. Hasil ini sama dengan hasil penelitian yang dilakukan oleh Rini (2009) bahwa terdapat hubungan antara tingkat pendapatan dengan kelengkapan imunisasi. Hal ini menunjukan bahwa tingkat pendapatan di Wonokusumo masih menjadi variabel yang berhubungan dengan melakukan imunisasi pada bayinya.

Penelitian ini didukung pula dengan hasil penelitian yang dilakukan oleh Rahmawati (2014) di Kota Surabaya tepatnya di Kelurahan Krembangan Utara, bahwa terdapat hubungan antara tingkat pendapatan dengan kelengkapan imunisasi dasar. Persamaan hasil penelitian di 
Wonokusumo dan Krembangan Utara adalah status ekonomi masyarakat samasama tergolong menengah kebawah. Status sosial ekonomi berhubungan erat dengan faktor psikologi pada masyarakat (Noor, 2000). Sehingga masyarakat menengah kebawah takut akan dikenakan biaya jika ke pelayanan imunisasi, meskipun pada dasarnya mereka mengetahui bahwa imunisasi dapat diperoleh secara gratis.

Hasil penelitian lain yang serupa juga pada negara perkembang seperti Nigeria (Adebiyi, 2013) dan Western Kenya (Luke, 2014), dimana ekonomi keluarga merupakan faktor yang berhubungan dengan kelengkapan imunisasi. Ekonomi keluarga ini dikaitkan dengan akses mendapatkan pelayanan kesehatan dan mewujudkan status kesehatan keluarga.

\section{Status Antenal}

Kunjungan antenatal merupakan kunjungan yang dilakukan oleh ibu saat kehamilaan. Dalam kunjungan antenatal ibu akan mendapatkan pemeriksaan dan konsultasi. Selain itu ibu akan mendapatkan informasi dan arahan seputar kehamilan dan juga kesehatan perawatan bayi setelah lahir. Kunjungan antenatal yang dianjurkan adalah minimal selama 4 kali. Ibu yang melakukan kunjungan antenatal maka akan mendapatkan paparan informasi dan himbauan tentang imunisasi dasar lengkap yang lebih banyak dibandingan dengan ibu yang melakukan kunjungan kurang dari 4 kali.

Hasil penelitian menunjukan nilai $p$ $<\alpha$ yang berartikan terdapat hubungan antara status antenatal ibu dengan kelengkapan imunisasi dasar. Hal ini dibuktikan dengan penelitian yang dilakukan oleh Luke (2013), bahwa ibu yang melakukan kunjungan antenatal paling tidak 4 kali akan melakukan imunisasi lengkap pada bayinya. Selain itu tedapat penelitian lainnya yang dilakukan oleh Etana (2012) menyatakan bahwa bayi yang diimunisasi lengkap berasal dari ibu yang mempunyai kunjungan antenatal sebanyak 4 kali atau lebih.

\section{Motivasi Ibu}

Motivasi adalah suatu alasan mendasar dalam bebuat sesuatu. Motivasi menjadi sebuah kehendak dorongan tetentu untuk melakukan sesuatu sampai tercapainya suatu tujuan tertentu. Motivasi menjadi suatu kekuatan, tenaga atau daya, atau suatu keadaan yang kompleks dan kesiapsediaan dalam diri individu untuk bergerak ke arah tujuan tertentu, baik disadari maupun tidak disadari. Motivasi seseorang dapat ditimbulkan dan tumbuh berkembang melalui dirinya sendiri atau intrinsik dan dari lingkungan atau ekstrinsik.

Hasil penelitian menunjukan nilai $p$ $<\alpha$ yang berartikan terdapat hubungan antara motivasi ibu dengan kelengkapan imunisasi dasar. Hasil ini sejalan dengan penelitian Triana (2015) yang mengatakan bahwa terdapat hubungan yang bemakna antara motivasi ibu dengan kelengkapan imunisasi.

Penelitian lainnya menghasilkan hasil yang serupa yaitu penelitian dari Senewe (2017) bahwa tedapat hubungan antara motivasi ibu dengan kepatuhan ibu dalam imunisasi dasar lengkap. Seorang ibu akan bersedia datang ke puskesmas atau posyandu untuk melakukan imunisasi pada bayinya karena memiliki motivasi yang tinggi yang didasari oleh berbagai faktor intrinsik maupun ekstrinsik.

\section{SIMPULAN}

Karakterisitik umur ibu di wilayah Wonokusumo sebanyak $94,19 \%$ ibu berusia lebih dari 20 tahun.Selanjutnya, 52,33\% ibu berpendidikan lebih dari 9 tahun dan $57,51 \%$ ibu memiliki pengetahuan yang baik tentang imunisasi dasar. Mayoritas ibu tidak bekerja yaitu sebanyak $74,42 \%$ dan berpenghasilan kurang dari UMK yaitu $70,93 \%$. Terdapat $76,74 \%$ ibu yang telah melakukan kunjungan antenatal lenih dari sama dengan 4 kali dan $68,60 \%$ ibu memiliki motivasi tinggi tentang imunisasi dasar.

Faktor karakteristik ibu yang memiliki hubungan dengan kelengkapan imunisasi dasar adalah pendidikan formal 
ibu, pengetahuan imunisasi, tingkat pendapatan, status antenal ibu, dan motivasi ibu. Variabel yang tidak berhubungan adalah umur ibu dan status bekerja ibu.

Berdasarkan hasil dan pembahasan diatas, maka saran yang dapat diberikan adalah memberikan penyuluhan untuk ibu bayi, serta wawasan tentang imunisasi saat ibu hamil melakukan kunjungan antenatal. Hal ini diperlukan untuk meningkatkan pengetahuan ibu tentang imunisasi sejak hamil.

\section{DAFTAR PUSTAKA}

Achmadi. 2006. Imunisasi Mengapa Perlu?. Jakarta: Karya Cetakan I.

Adebiyi, F. 2013. Determinants of Full Child Immunization Among 12-23 Months Old In Nigeria. Thesis. University of The Witwatersrand.

Afriani, T., Andrajati, R., Supardi, S. 2014. Faktor-Faktor Yang Berhubungan Dengan Kelengkapan Imunisasi Dasar Pada Anak Dan Pengelolaan Vaksin Di Puskesmas Dan Posyandu Kecamatan X Kota Depok. Buletin Penelitian Sistem Kesehatan.

Arifianto. 2014. Pro Kontra Imunisasi. Noura Books. Jakarta:113-271.

Etana, B., Deressa, W. 2012. Factors Associated With Complete Imminization Coverage in Children aged $12-23$ Months in Amboworeda, Central Ethiopia. BMC Public Health, 2012(12): 566. [https:// https://doi.org/10.1186/1471-245812-566]

Dwiastuti, P., Prayitno, N. 2013. FaktorFaktor yang Berhubungan dengan Pemberian Imunisasi BCG di Wilayah Puskesmas UPT Cimanggis Kota Depok Tahun 2012. Jurnal Ilmiah Kesehatan, 5(1): pp.36-46

Green L.W., dan Kreuter M.W., 1999. Health Promotion Planning: An Educational and Ecological Approach 3rd Edition. California: Mayfield Publishing Co.
Indrawan, I. B. M. 2014. Hubungan Pegetahuan Serta Dukungan Keluarga dengan Peran Kader dalam Pencapaian UCI Kelurahan. Jurnal Berkala Epidemiologi, 2(1): pp.8392.[https://doi=10.20473/jbe.V2I120 14.83-92]

Isnayni, E. 2016. Hubungan Karakteristik Ibu dan Peran Keluarga (Inti dan Non Inti) dengan Kelengkapan Imunisasi Dasar pada Bayi di Puskesmas Pucuk Kabupaten Lamongan.Jurnal Berkala Epidemiologi, 4(3): pp.360-370. [https://doi=10.20473/jbe.V4I32016. 360-370]

Luke, J. S. 2014. Family Factors Associated With Immunization Uptake In Children Aged Between 12-59 Months: A Household Survey In Kakamega Central District, Western Kenya. Thesis. Auckland University of Technology.

Menteri Kesehatan RI. 2016. Pusdatin Kemenkes Profil Kesehatan Indonesia. Indonesia: Kementerin Kesehatan RI.

Ningrum, P. E. 2008. Faktor-Faktor Yang Mempengaruhi Kelengkapan Imunisasi Dasar Pada Bayi di Puskesmas Bayudono Kabupaten Boyolali.

Octaviani, F. A. 2015. Faktor yang Mempengaruhi Penolakan Ibu Terhadap Pemberian Imunisasi Dasar Lengkap di Wilayah Puskesmas Kamoning Kabupaten Sampang Tahun 2014. Skripsi. Universitas Airlangga.

Pratiwi, L. N. 2012. Faktor-Faktor yang Berhubungan dengan Status Imunisasi Dasar pada Balita Umur 12-23 Bulan di Indonedia Tahun 2010. Skripsi. Universitas Indonesia.

Rahmawati, A., I. 2014. Faktor yang Mempengaruhi Kelengkapan Imunisasi Dasar di Kelurahan Krembangan Utara. Jurnal Berkala Epidemiologi, 2(1): pp: 59-70. [https://doi=10.20473/jbe.V2I12014. 59-70] 
Ramadhani, R. B. 20130. Faktor-Faktor yang Berhubungan dengan Kelengkapan Imunisasi Dasar Balita di Desa Balegondo Kecamatan Ngariboyo Kabupaten Magetan. Skripsi. Universitas Muhammadiyah Surakarta

Ranuh, I. G. N., Suyitno, H., Hadinegoro, S.R.H., Kartasasmita, C.B. 2011. Pedoman Imunisasi di Indonesia. Edisi Ketiga. Jakarta: Badan Penerbit Ikatan Dokter Anak Indonesia.

Rini, A. P. 2009. Hubungan Antara Karakteristik Ibu, Jumlah Anak dan Pengetahuan Ibu Terhadap Status Kelengkapan Imunisasi Dasar pada Bayi di Kelurahan Wonokusumo Kecamatan Semampir Surabaya Tahun 2008. Skripsi. Universitas Airlangga.

Rizqiwan, A., 2008. Faktor yang Mempengaruhi Ibu dalam Ketidakikutsertaan Balitanya ke
Pekan Imunisasi Nasional (PIN) Polio di Wilayah Kerja Puskesmas Mulyorejo Surabaya. Skripsi. Universitas Airlangga.

Sarafino, E. P. 2006. Health Psychology: Biopsychosocial Interaction $5^{\text {th }} e d$. New York: John Willey and Sons, Inc.

Siska, P. 2010. Hubungan Kepatuhan Melakukan Imunisasi Dasar Dengaan Angka Kejadian PD31 Pada Anak SDN 01 Pondok Labu Jakarta Selatan.

Sugiarti. 2014. Faktor-faktor yang Mempengaruhi Kepatuhan Ibu dalam Pemberian Imunisasi Dasar pada Balita. Jurnal Kebidanan Griya Husada.

Triana, V. 2016. Faktor Yang Berhubungan Dengan Pemberian Imunisasi Dasar Lengkap Pada Bayi Tahun 2015. Jurnal Kesehatan Masyarakat Andalas, 10(2): pp.123-135. 